\section{Performance of 'Ponkan' Mandarin on Seven Rootstocks in Southern Brazil}

\author{
Neusa M.C. Stenzel ${ }^{1}$ \\ Agricultural Research Institute of Paraná - IAPAR, CP 481 CEP-86001-970- \\ Londrina, PR, Brazil
}

Carmen S.V.J. Neves ${ }^{2}$

State University of Londrina-UEL, CP 6001, CEP-86051-990-Londrina, PR, Brazil

\author{
José C. Gomes ${ }^{3}$ \\ Agricultural Research Institute of Paraná-IAPAR, CP 481 CEP-86001-970- \\ Londrina, PR, Brazil
}

Cristiane C. Medina ${ }^{2}$

State University of Londrina-UEL, CP 6001 CEP-86051-990-Londrina, PR, Brazil

Additional index words. yield, tree size, fruit quality, Citrus reticulata, alternate bearing index

\begin{abstract}
This study reports the performance (yield, tree size, and fruit quality) of 'Ponkan' mandarin (Citrus reticulata Blanco) on seven rootstocks, evaluated for 11 years under Southern Brazil conditions. Trees on $\mathrm{C} 13$ citrange had higher cumulative yield for seven harvests than those on trifoliate orange. Cleopatra mandarin, rough lemon, Rangpur lime, Sunki mandarin, and Volkamer lemon rootstocks maintained their values at an intermediate position and did not present any significant difference regarding $\mathrm{C} 13$ citrange, and trifoliate orange. Trees on C13 citrange and on trifoliate orange exhibited the lowest alternate bearing index. Cleopatra mandarin induced the greatest canopy volume, but it was not significantly different from Sunki mandarin and rough lemon. The smallest trees were those on Volkamer lemon and trifoliate orange. The highest yield efficiency came from trees on C13 citrange and the smallest on Cleopatra mandarin. Rootstocks did not significantly affect fruit weight.
\end{abstract}

'Ponkan' (Citrus reticulata Blanco) is an early midseason mandarin. The trees are vigorous with upright growth habit, and are productive, but with a tendency to alternate bear. The fruits are tender and juicy with a mild, pleasant, and aromatic flavor, an orange flesh color, and rind puffs. 'Ponkan' mandarin is also known as 'Batangas', 'Nagpur Suntara', or 'Santra', and has a good reputation in the South of China, Formosa, and India (Hodgson, 1967). In Brazil, this mandarin is the most important one, and is mainly grown in southeast and southern regions, where it shows an excellent adaptation to soil and climatic conditions. Rangpur lime (Citrus limonia Osb.) is the main rootstock used for 'Ponkan' mandarin in Brazil (Pompeu Júnior, 1991). Rangpur lime has performed well and grows satisfactorily in the presence of citrus tristeza virus; however, it has a moderate tolerance to Phytophthora citrophthora (R.E. Sm. and E.H. Sm.) Leonian and Phytophthora parasitica Dastur, and is susceptible to citrus blight (Timmer et al., 1984). Citrus rootstocks have interactive effects on tree size, yield and

Received for publication 20 Dec. 2001. Accepted for publication 25 June 2002

${ }^{1}$ Research Horticulturist.E-mail address:nstenzel@ pr.gov.br

${ }^{2}$ Professor.

${ }^{3}$ Research, Dept. Biometry. fruit quality. Therefore, it is important to evaluate the performance of 'Ponkan' mandarin on rootstocks in regions where it is cultivated because the results from rootstock research can vary from area to area due to climate, soil, diseases, and cultural practices (Wutscher and Bistline, 1988). In Brazil, research on citrus rootstocks are mostly from São Paulo state and for orange cultivars, because orange is $95 \%$ of citrus growing in Brazil. So, there is a lack of information on rootstocks under other conditions and for mandarin cultivars. The aim of this study was to evaluate the performance of 'Ponkan' mandarin on seven rootstocks, 11 years after planting in the state of Paraná, southern Brazil.

\section{Materials and Methods}

The rootstocks tested were: $\mathrm{C} 13$ citrange [Citrus sinensis (L.) Osb. x Poncirus trifoliata (L.) Raf.], a selection from Brazil; Cleopatramandarin (C. reticulata Blanco); rough lemon (C. jambhiri Lush.); Rangpur lime ( $C$. limonia Osb.); Sunki mandarin (C. reticulata var. austera Swing.); Volkamer lemon ( $C$. Volkameriana Ten. and Pasq.); and trifoliate orange [Poncirus trifoliata (L.) Raf.]. These rootstocks were chosen because they are the main ones used in most citrus-growing countries. The rootstocks were propagated from seeds obtained from productive and virusfree trees. The seedlings were T-budded with a virus-free 'Ponkan' mandarin. Seeds and buds were obtained from a germplasm collection at the Agricultural Research Institute of Paraná (IAPAR). The trees were planted in Dec. 1988, at a commercial grove in Paraná State, Brazil (lat. $23^{\circ} 27^{\prime} \mathrm{S}$; long. $51^{\circ} 59^{\prime} \mathrm{W}, 500$ $\mathrm{m}$ altitude), with $7.0 \times 4.0 \mathrm{~m}$ spacing. The soil type in the experimental area was a clayey Typic Haplorthox, with $600 \mathrm{~g} \cdot \mathrm{kg}^{-1}$ of clay, $70 \mathrm{~g} \cdot \mathrm{kg}^{-1}$ of silt, $330 \mathrm{~g} \cdot \mathrm{kg}^{-1}$ of sand, and $\mathrm{pH} 4.61$ in the $0-25 \mathrm{~cm}$ soil layer. The climate classification is Cfa according to Köppen, and the area has an average annual rainfall of $1,504 \mathrm{~mm}$, occurring mainly in the spring and summer. The average temperature ranges from $17.7^{\circ} \mathrm{C}$ to $28.3{ }^{\circ} \mathrm{C}$, and relative humidity $(\mathrm{RH})$ ranges from $70 \%$ to $75 \%$ (Caviglione et al., 2000).

The experiment had a randomized complete-block design, with three-tree plots and four replications. The experimental site was surrounded on all sides by 'Ponkan' mandarin trees on Rangpur lime rootstock. The trees received standard commercial care for disease control, fertilization, and chemical weed control within the rows. The areas between rows were covered with grass. Foliar spray nutrients were applied when leaf analysis indicated a deficiency. The trees were not irrigated, a common practice in the commercial orchards of southern Brazil.

Fruits were harvested and weighed in April and May, from the seasons of 1992 until 1999 (except 1998, probably due to low rainfall during flowering that year). Tree height and width were measured in June, 1991, and 1999, and canopy volume was calculated by the formula [volume = $(4 / 6) \cdot \pi \cdot$ height $\cdot$ radius $\left.^{2}\right]$. The ratio of the average yield (1992-99) to the average volume (1992-99), was calculated to estimate the yield efficiency for each rootstock. The fluctuation in yield was expressed in terms of alternate bearing index (I), calculated as $\mathrm{I}=$ $1 / \mathrm{n}-1 \times\left\{\left|\left(\mathrm{a}_{2}-\mathrm{a}_{1}\right)\right| /\left(\mathrm{a}_{2}+\mathrm{a}_{1}\right)+\left|\left(\mathrm{a}_{3}-\mathrm{a}_{2}\right)\right| /\left(\mathrm{a}_{3}\right.\right.$ $\left.\left.+a_{2}\right)+\ldots+\left|\left(a_{(n)}-a_{(n-1)}\right)\right| /\left(a_{(n)}+a_{(n-1)}\right)\right\}$, where $\mathrm{n}=$ number of years, and $\mathrm{a}_{1}, \mathrm{a}_{2}, \ldots, \mathrm{a}_{(\mathrm{n}-1)}, \mathrm{a}_{(\mathrm{n})}$ $=$ yields of corresponding years (Pearce and Dobersek-Urbanc, 1967). In 1994, 3 d before harvest, an eight-fruit sample was taken from each plot and then analyzed for fruit quality. Fruits were weighed and juice was extracted with an electric reamer. The juice content was measured, also the total soluble solids (TSS) were determined with a refractometer and total acids (TA) (as citric acid equivalent) by titration with $0.1 \mathrm{~N} \mathrm{NaOH}$

Data were analyzed using SAS program (SAS Institute, 1989) for analysis of variance (ANOVA), in order to evaluate rootstock effects on 'Ponkan' mandarin characteristics. Covariance analysis was used to factor out the influence of canopy volume on the yield. The means were separated by Duncan's multiple range test at $P \leq 0.05$.

\section{Results and Discussion}

No effect of rootstocks on trees for canopy diameter and canopy volume occurred in 1991 
Table 1. Tree height, canopy diameter and canopy volume in 1991 and 1999, of 'Ponkan' mandarin trees on seven rootstocks in southern Brazil.

\begin{tabular}{|c|c|c|c|c|c|c|}
\hline \multirow[b]{2}{*}{ Rootstock } & \multicolumn{2}{|c|}{ Tree height $(\mathrm{m})$} & \multicolumn{2}{|c|}{ Canopy diameter $(\mathrm{m})$} & \multicolumn{2}{|c|}{ Canopy volume $\left(\mathrm{m}^{3}\right)$} \\
\hline & 1991 & 1999 & 1991 & 1999 & 1991 & 1999 \\
\hline C13 citrange & $2.72 \mathrm{ab}^{\mathrm{z}}$ & $4.82 \mathrm{bc}$ & $1.4 \mathrm{a}$ & $4.4 \mathrm{bc}$ & $2.9 \mathrm{a}$ & $50.5 \mathrm{bc}$ \\
\hline Cleopatra mandarin & $2.82 \mathrm{ab}$ & $5.57 \mathrm{a}$ & $1.3 \mathrm{a}$ & $5.0 \mathrm{a}$ & $2.9 \mathrm{a}$ & $72.3 \mathrm{a}$ \\
\hline Rough lemon & $2.67 \mathrm{bc}$ & $5.25 \mathrm{ab}$ & $1.4 \mathrm{a}$ & $4.7 \mathrm{ab}$ & $2.9 \mathrm{a}$ & $60.5 \mathrm{ab}$ \\
\hline Rangpur lime & $2.60 \mathrm{bc}$ & $4.82 \mathrm{bc}$ & $1.3 \mathrm{a}$ & $4.4 \mathrm{bc}$ & $2.6 \mathrm{a}$ & $50.2 \mathrm{bc}$ \\
\hline Sunki mandarin & $3.00 \mathrm{a}$ & $5.42 \mathrm{a}$ & $1.4 \mathrm{a}$ & $4.6 \mathrm{ab}$ & $3.2 \mathrm{a}$ & $59.7 \mathrm{ab}$ \\
\hline Volkamer lemon & $2.40 \mathrm{c}$ & $4.37 \mathrm{c}$ & $1.2 \mathrm{a}$ & $4.1 \mathrm{c}$ & $2.0 \mathrm{a}$ & $38.5 \mathrm{c}$ \\
\hline Trifoliate orange & $2.52 \mathrm{~b}$ & $4.42 \mathrm{c}$ & $1.3 \mathrm{a}$ & $4.4 \mathrm{bc}$ & $2.2 \mathrm{a}$ & $45.6 \mathrm{c}$ \\
\hline
\end{tabular}

${ }^{2}$ Mean separation within columns by Duncan's multiple range test at $P \leq 0.05$.

Table 2. Annual and cumulative yield of seven harvests (1992-99) except 1998, mean yield efficiency, and alternate bearing index of 'Ponkan' mandarin trees on seven rootstocks in southern Brazil.

\begin{tabular}{|c|c|c|c|c|c|c|c|c|c|c|c|}
\hline Rootstock & 1992 & 1993 & 1994 & 1995 & 1996 & 1997 & 1999 & $\begin{array}{c}\text { Cumulative } \\
\text { yield } \\
\text { (original data) } \\
1992-99 \\
\end{array}$ & $\begin{array}{c}\text { Cumulative } \\
\text { yield } \\
\text { (corrected data) }^{\mathrm{z}} \\
1992-99 \\
\end{array}$ & $\begin{array}{c}\text { Mean yield } \\
\text { efficiency } \\
\left(\mathrm{kg} \cdot \mathrm{m}^{-3}\right) \\
1992-99 \\
\end{array}$ & $\begin{array}{c}\text { Alternate } \\
\text { bearing } \\
\text { index } \\
\text { 1992-99 } \\
\end{array}$ \\
\hline & \multicolumn{11}{|c|}{ Yield/tree (kg) } \\
\hline C13 citrange & $20.9 a^{y}$ & $84.3 \mathrm{ab}$ & $151.3 \mathrm{a}$ & $115.1 \mathrm{ab}$ & $172.0 \mathrm{a}$ & $135.8 \mathrm{a}$ & $163.0 \mathrm{ab}$ & 842.4 & $869.7 \mathrm{a}$ & $4.0 \mathrm{a}$ & $0.28 \mathrm{~b}$ \\
\hline Cleopatra mandarin & $12.5 \mathrm{ab}$ & $90.8 \mathrm{ab}$ & $147.7 \mathrm{a}$ & $147.6 \mathrm{a}$ & $105.0 \mathrm{ab}$ & $151.7 \mathrm{a}$ & $184.6 \mathrm{a}$ & 840.0 & $692.9 \mathrm{ab}$ & $2.9 \mathrm{~b}$ & $0.36 \mathrm{ab}$ \\
\hline Rough lemon & $29.4 \mathrm{a}$ & $73.0 \mathrm{ab}$ & $174.5 \mathrm{a}$ & $116.2 \mathrm{ab}$ & $116.2 \mathrm{ab}$ & $82.2 \mathrm{a}$ & $169.5 \mathrm{ab}$ & 761.2 & $708.4 \mathrm{ab}$ & $3.1 \mathrm{ab}$ & $0.38 \mathrm{ab}$ \\
\hline Rangpur lime & $20.3 \mathrm{ab}$ & $42.3 \mathrm{~b}$ & $181.8 \mathrm{a}$ & $109.6 \mathrm{ab}$ & $42.7 \mathrm{~b}$ & $125.3 \mathrm{a}$ & $173.4 \mathrm{ab}$ & 695.6 & $725.1 \mathrm{ab}$ & $3.3 \mathrm{ab}$ & $0.48 \mathrm{a}$ \\
\hline Sunki mandarin & $22.5 \mathrm{ab}$ & $114.2 \mathrm{a}$ & $136.6 \mathrm{a}$ & $42.4 \mathrm{c}$ & $34.0 \mathrm{~b}$ & $137.5 \mathrm{a}$ & $181.7 \mathrm{a}$ & 669.0 & $622.7 \mathrm{ab}$ & $3.7 \mathrm{ab}$ & $0.46 \mathrm{a}$ \\
\hline Volkamer lemon & $30.1 \mathrm{a}$ & $70.7 \mathrm{ab}$ & $128.8 \mathrm{a}$ & $118.3 \mathrm{ab}$ & $107.0 \mathrm{ab}$ & $90.3 \mathrm{a}$ & $118.0 \mathrm{c}$ & 663.3 & $786.3 \mathrm{ab}$ & $3.4 \mathrm{ab}$ & $0.33 \mathrm{ab}$ \\
\hline Trifoliate orange & $9.4 \mathrm{~b}$ & $70.5 \mathrm{ab}$ & $87.6 \mathrm{a}$ & $86.4 \mathrm{bc}$ & $59.0 \mathrm{~b}$ & $84.3 \mathrm{a}$ & $133.1 \mathrm{bc}$ & 530.4 & $596.5 \mathrm{~b}$ & $3.8 \mathrm{ab}$ & $0.31 \mathrm{~b}$ \\
\hline
\end{tabular}

${ }^{2}$ Data corrected by covariance analysis, using tree canopy volume as the co-factor.

${ }^{y}$ Mean separation within columns by Duncan's multiple range test at $P \leq 0.05$.

(Table 1). As for tree height, trees on Sunki mandarin showed the highest values, but were not statistically different from Cleopatra mandarin or C13 citrange, and those on Volkamer lemon were significantly lower than trees on other rootstocks. In 1999, rootstocks influenced tree height, canopy diameter and canopy volume. Cleopatra mandarin induced the highest values of tree height, canopy diameter, and canopy volume; however, values were not significantly different from Sunki mandarin or rough lemon. The smallest trees were those on Volkamer lemon and trifoliate orange, which did not differ significantly from trees on Rangpur lime and C13 citrange. Similarly, results with Cleopatra mandarin and trifoliate orange rootstocks were also observed with 'Ponkan' mandarin trees (Parente et al., 1993); 'Pineapple' orange, 'Clementine' mandarin, 'Tahiti' lime, and 'Orlando' tangelo trees (Grisoni et al.,1989); and 'Ponkan'mandarin on Cleopatra mandarin (Valbuena, 1994).

Yield in seven harvests from 1992 to 1999 (except 1998) indicated a difference in productivity among rootstocks (Table 2). Trees on $\mathrm{C} 13$ citrange had the highest cumulative yield, but differed significantly only from trifoliate orange. Yields on other rootstocks were intermediate, and did not show any significant difference in relation to $\mathrm{C} 13$ citrange, or trifoliate orange. Figueiredo et al. (1973) obtained similar results with higher cumulative yield of 'Ponkan' mandarin on Troyer citrange and Rangpur lime; however there was no difference from each other in the state of São Paulo, Brazil. Fallahi and Rodney (1992) reported the highest yield for 'Fairchild' mandarin on 'Carrizo' citrange. In Florida, 'Carrizo' citrange is considered as a general purpose rootstock due to its vigor and yield in all soils except those with high levels of available calcium (Castle et al., 1989).

In this experiment, trees on Cleopatra mandarin and trifoliate orange were less precocious than the other rootstocks at the first harvest. However, the cumulative yield of trees on Cleopatra mandarin was higher. According to Pompeu Júnior (1991), citrus trees budded on Rangpur lime, rough lemon, Volkamer lemon and trifoliate orange are productive as young trees, while Cleopatra mandarin has medium yield as young trees. In Florida conditions, Volkamer lemon and 'Carrizo' citrange rootstocks are also productive as young trees, and trees on Cleopatra mandarin produce relatively poorly until the trees are 10-15 years old, however performance on Cleopatra mandarin depends on the scion (Castle et al., 1989).

Trees on $\mathrm{C} 13$ citrange presented the highest yield efficiency, although it was significantly different only from trees on Cleopatra mandarin, which had the lowest yield efficiency due to its higher values for height and canopy (Table 2). Favorable results in terms of yield efficiency are also cited by Georgiou (2000) for 'Nova' mandarin on 'Carrizo' citrange and Rangpur lime. The alternate bearing index was lower for trees on $\mathrm{C} 13$ citrange and trifoliata orange. These rootstocks were significantly different from Rangpur lime and Sunki mandarin, but had no difference from Cleopatra mandarin, rough lemon, or Volkamer lemon (Table 2).

Rootstocks did not significantly affect fruit weight (Table 3). Rough lemon has been widely used in Florida for the small-fruited 'Dancy' mandarin and trifoliate orange rootstock reduces fruit size (Castle et al., 1989). Juice content was higher for Rangpur lime, and significantly lower for $\mathrm{C} 13$ citrange, rough lemon, Volkamer lemon and Sunki mandarin. Total soluble solids (TSS) of fruits on trifoliate orange 0 was greater than that on on $\mathrm{C} 13$ citrange. Minimum total acids (TA) were in fruits from trees on rough lemon, while all other rootstocks induced fruits with a higher TA. Fruits from trees on rough lemon had the highest ratio (TSS:TA), but were different only from trees on $\mathrm{C} 13$ citrange, which had the lowest ratio. Parente et al. (1993) also had higher ratio and lower TA with rough lemon on
Table 3. Fruit quality analysis of 'Ponkan' mandarin on seven rootstocks in southern Brazil (harvest 1994).

\begin{tabular}{lccccc}
\hline & $\begin{array}{c}\text { Fruit wt } \\
(\mathrm{g})\end{array}$ & $\begin{array}{c}\text { Juice } \\
\text { content } \\
(\%)\end{array}$ & $\begin{array}{c}\text { Total soluble } \\
\text { solids (TSS) } \\
(\%)\end{array}$ & $\begin{array}{c}\text { Total acids } \\
(\text { TA }) \\
(\%)\end{array}$ & $\begin{array}{c}\text { TSS:TA } \\
\text { ratio }\end{array}$ \\
\hline C13 citrange & $225.0 \mathrm{a}^{\mathrm{z}}$ & $24.1 \mathrm{~b}$ & $6.6 \mathrm{~b}$ & $0.52 \mathrm{a}$ & $13.0 \mathrm{~b}$ \\
Cleopatra mandarin & $242.5 \mathrm{a}$ & $28.1 \mathrm{ab}$ & $7.0 \mathrm{ab}$ & $0.47 \mathrm{ab}$ & $14.9 \mathrm{ab}$ \\
Rough lemon & $247.5 \mathrm{a}$ & $21.8 \mathrm{~b}$ & $7.0 \mathrm{ab}$ & $0.41 \mathrm{~b}$ & $17.8 \mathrm{a}$ \\
Rangpur lime & $209.0 \mathrm{a}$ & $36.5 \mathrm{a}$ & $7.1 \mathrm{ab}$ & $0.49 \mathrm{ab}$ & $14.9 \mathrm{ab}$ \\
Sunki mandarin & $230.0 \mathrm{a}$ & $25.3 \mathrm{~b}$ & $7.2 \mathrm{ab}$ & $0.50 \mathrm{a}$ & $14.6 \mathrm{ab}$ \\
Volkamer lemon & $262.5 \mathrm{a}$ & $26.7 \mathrm{~b}$ & $7.6 \mathrm{ab}$ & $0.51 \mathrm{a}$ & $15.1 \mathrm{ab}$ \\
Trifoliate orange & $242.5 \mathrm{a}$ & $29.6 \mathrm{ab}$ & $7.8 \mathrm{a}$ & $0.54 \mathrm{a}$ & $14.4 \mathrm{ab}$ \\
\hline
\end{tabular}

${ }^{\text {z} M e a n ~ s e p a r a t i o n ~ w i t h i n ~ c o l u m n s ~ b y ~ D u n c a n ' s ~ m u l t i p l e ~ r a n g e ~ t e s t ~ a t ~} P \leq 0.05$. 
'Ponkan'. Similarly, lower ratios were reported with 'Temple' mandarin on 'Carrizo' citrange (Levy et al., 1993).

Based on these results, in terms of yield all the evaluated rootstocks except trifoliate orange would be suitable to 'Ponkan' mandarin in Parana state as well as other regions that present similar soil and climate conditions. The rootstocks that presented lower alternate bearing index were $\mathrm{C} 13$ citrange and trifoliata orange.

\section{Literature Cited}

Castle, S.W., D.P.H. Tucker, H.A. Krezdorn, and C.O. Youtsey. 1989. Rootstocks for Florida Citrus. Inst. Food Agr. Sci., Univ. of Florida, Gainesville, p. 47.

Caviglione, J.H., L.R.B. Kiihl, P.H. Caramori, and D. Oliveira. 2000. Cartas climáticas do Paraná IAPAR. Versão 1. CD-ROM.

Fallahi,E. and R. Rodney. 1992. Tree size, yield, fruit quality, and leaf mineral nutrient concentration of 'Fairchild' mandarin on six rootstocks. J. Amer.
Soc. Hort. Sci. 117:28-31.

Figueiredo, J.O., J. Pompeu Júnior, O. Rodriguez, A.A. Viegas, and E. Abramides. 1973. Competição de dez porta-enxertos para a tangerina Poncã (Citrus reticulata Blanco). Anais $2^{\text {nd }}$ Congresso Brasileiro de Fruticultura.Viçosa, MG, Brazil. 1:127-147.

Georgiou,A. 2000. Performance of 'Nova' mandarin on eleven rootstocks in Cyprus. Scientia Hort. 84:115-126.

Grisoni, M.,P.Cabeu, and B. Aubert. 1989. Résultats de douze années d'um essai de comportement de cinq porte-greffe em association avec quatre cultivars d'agrumes à l'île de la Réunion. Fruits 44:529-538.

Hodgson, R.W. 1967. Horticultural varieties of citrus. In: Reuther, W., H.J. Webber, and L.D. Batchelor, (eds.). The citrus industry. Univ. of California, Riverside. p. 431-592.

Levy, Y., J.Lifshitz, and N. Bavli. 1993. Alemow (Citrus macrophylla Wester) - Adwarfing rootstock for old-line 'Temple' mandarin (Citrus temple Hort. ex. Tan.). Scientia Hort. 53:289-300.

Parente, T.V., F.S. Wechsler, L.A. Borgo, and L.P. Rezende. 1993. Comportamento da tangerina
Ponkan (Citrus reticulata Blanco) sobre 14 porta-enxertos do Distrito Federal. Revista Brasileira de Fruticultura 15: 35-41.

Pearce, S.C. and S. Dobersek-Urbanc. 1967. The measurements of irregularity in growth and cropping. J. Hort. Sci., 42:295-305.

Pompeu Júnior, J. 1991. Porta-enxertos. In: Citricultura Brasileira (Rodriguez, O., F.C.P. Viegas, J. Pompeu Júnior, and A.A. Amaro, eds.). Fundação Cargill, Campinas. p. 265-280.

SAS Institute. 1989. SAS/STAT user's guide, version 6, 4th ed., 1. Cary, N.C.

Timmer, L.W., R.H. Brlansky, R.F. Lee, and J.H. Graham. 1984. Characteristics of citrus trees affected by blight in Florida, by declinamiento in Argentina, and by declino in Brazil. Proc. Intl. Soc. Citricult. 2:371-374.

Valbuena, M. 1994. Comportamiento agronómico de algunas combinaciones copas-patrones de cítricos, en la zona media del río Guasare, Zulia, Venezuela. Rev. Fac. Agron. (LUZ) 11:1-12.

Wutscher,H.K. and F.W. Bistline. 1988. Performance of 'Hamlin' orange on 30 citrus rootstocks in Southern Florida. J. Amer. Soc. Hort. Sci. 113: 493-497. 